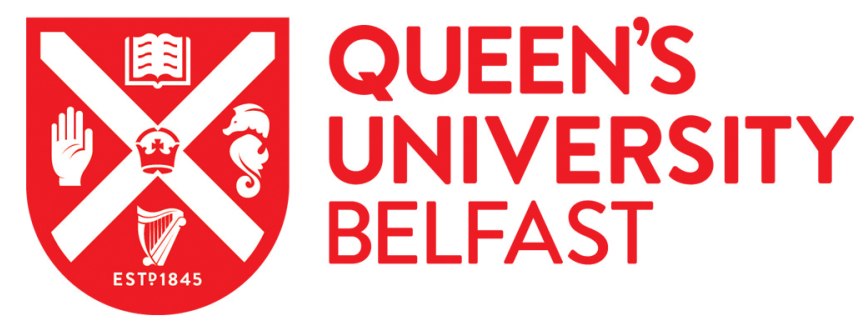

\title{
Historical data reveal power-law dispersal patterns of invasive aquatic species
}

Kelly, R., Lundy, M. G., Mineur, F., Harrod, C., Maggs, C. A., Humphries, N. E., Sims, D. W., \& Reid, N. (2014). Historical data reveal power-law dispersal patterns of invasive aquatic species. Ecography, 37(6), 581-590. https://doi.org/10.1111/j.1600-0587.2013.00296.x

\section{Published in: \\ Ecography}

\section{Document Version:}

Peer reviewed version

Queen's University Belfast - Research Portal:

Link to publication record in Queen's University Belfast Research Portal

\section{Publisher rights}

This is the accepted version of the following article: Kelly, R., Lundy, M. G., Mineur, F., Harrod, C., Maggs, C. A., Humphries, N. E., Sims, D. W. and Reid, N. (2014), Historical data reveal power-law dispersal patterns of invasive aquatic species. Ecography, 37: 581-590 which has been published in final form at http://dx.doi.org/10.1111/j.1600-0587.2013.00296.x.

\section{General rights}

Copyright for the publications made accessible via the Queen's University Belfast Research Portal is retained by the author(s) and / or other copyright owners and it is a condition of accessing these publications that users recognise and abide by the legal requirements associated with these rights.

Take down policy

The Research Portal is Queen's institutional repository that provides access to Queen's research output. Every effort has been made to ensure that content in the Research Portal does not infringe any person's rights, or applicable UK laws. If you discover content in the Research Portal that you believe breaches copyright or violates any law, please contact openaccess@qub.ac.uk. 


\section{Historical data reveal power-law dispersal patterns of invasive}

\section{2 aquatic species}

3

4 Ruth Kelly ${ }^{1 *}$, Mathieu G. Lundy ${ }^{1,2}$, Frédéric Mineur ${ }^{3,4}$, Chris Harrod ${ }^{3,5}$, Christine A. Maggs ${ }^{3}$,

$5 \quad$ Nicolas E. Humphries ${ }^{6,7}$, David W. Sims ${ }^{6,8,9}$, Neil Reid ${ }^{1}$

$7 \quad{ }^{1}$ Quercus, School of Biological Sciences, Queen's University Belfast, Belfast BT9 7BL, UK

$8{ }^{2}$ Agri-food and Biosciences Institute, Fisheries Aquatic Ecosystems Branch, Newforge Lane,

9 Belfast, BT9 5PX, UK

$10{ }^{3}$ School of Biological Sciences, Queen's University Belfast, Belfast, BT9 7BL, UK

$11{ }^{4}$ Mediterranean Institute of Oceanography, 13288, Marseille, France

$12{ }^{5}$ Facultad de Recursos del Mar, Instituto de Investigaciones Oceanológicas, Universidad

13 Antofagasta, Chile

${ }^{6}$ Marine Biological Association of the United Kingdom, The Laboratory, Citadel Hill, Plymouth PL1 2PB, UK

${ }^{7}$ School of Marine Science and Engineering, Marine Institute, University of Plymouth, Drake

17 Circus, Plymouth PL4 8AA, UK

${ }^{8}$ Ocean and Earth Science, National Oceanography Centre Southampton, University of Southampton, Waterfront Campus, European Way, Southampton SO14 3ZH, UK

${ }^{9}$ Centre for Biological Sciences and Institute for Life Sciences, Building 85, University of

*Corresponding author: Tel.: +44 289097 2281, +44 77 07627488, Fax: +44 289097 
Abstract

Understanding how invasive species spread is of particular concern in the current era of globalisation and rapid environmental change. The occurrence of super-diffusive movements within the context of Lévy flights, has been discussed with respect to particle physics, human movements, microzooplankton, disease spread in global epidemiology and animal foraging behaviour. Super-diffusive movements provide a theoretical explanation for the rapid spread of organisms and disease (Viswanthan, 2010), but their applicability to empirical data on the historic spread of organisms has rarely been tested. This study focuses on the role of longdistance dispersal in the invasion dynamics of aquatic invasive species across three contrasting areas and spatial scales: open ocean (North-East Atlantic), enclosed sea (Mediterranean) and an island environment (Ireland). Study species included five freshwater plant species, Azolla filiculoides, Elodea canadensis, Lagarosiphon major, Elodea nuttallii and Lemna minuta; and ten species of marine algae, Asparagopsis armata, Antithamnionella elegans, Antithamnionella ternifolia, Codium fragile, Colpomenia peregrina, Caulerpa taxifolia, Dasysiphonia sp., Sargassum muticum, Undaria pinnatifida and Womersleyella setacea. A simulation model is constructed to show the validity of using historical data to reconstruct dispersal kernels. Lévy movement patterns similar to those previously observed in humans and wild animals are evident in the re-constructed dispersal pattern of invasive aquatic species. Such patterns may be widespread among invasive species and could be exacerbated by further development of trade networks, human travel and environmental change. These findings have implications for our ability to predict and manage future invasions, and improve our understanding of the potential for spread of organisms including infectious diseases, plant pests and genetically modified organisms. 
Modelling the spread of species is a key issue in ecology and has important implications for many fields of environmental change research including palaeoecology (Clark, 1998), invasion biology (Shigesada et al., 1995; Yamamura et al., 2006), epidemiology (Mundt, et al. 2009), climate change modelling (Higgins \& Harte, 2006) and restoration of degraded landscapes (Nathan et al. 2008). In invasion biology, predicting rates of species spread is essential in formulating guidance for managers (Bullock et al., 2008) and in planning national control strategies.

Historically descriptions of patterns of species' spread have been based on classical 'reaction diffusion' models, which incorporate parameters of species reproduction and dispersal rates. These models suggest that the spread of a population, in terms of the distance from the point of introduction, increases linearly with time (and therefore the square root of the occupied area also increases linearly due to the relationship between area and radius in a two dimensional plane: see Skellam 1951 for mathematical derivations). Reaction diffusion models assume that dispersal kernels conform to a normal distribution (Williamson et al., 2005). However, empirical data on dispersal are frequently leptokurtic (Kot et al., 1996). Rates of spread are extremely sensitive to the frequency of long-distance dispersal events (Shigesada et al., 1995; Clark, 1998; Kot et al., 1996). Indeed, it has been demonstrated that rates of spread can increase by an order of magnitude even when the frequency of longdistance dispersal is extremely low, for example, $0.1 \%$ of dispersal events (Higgins \& Richardson, 1999). Classical reaction diffusion models are therefore likely to substantially underestimate rates of spread where long-distance dispersal occurs. In addition, theoretical models suggest that frequent long distance dispersal events may diminish the role of life history traits and landscape factors in determining the rate of species spread (Marco et al., 2011). 
Simulations of the evolution of plant dispersal have shown that dispersal curves with a generalized power law form that predict a non-zero probability of propagules dispersing over very long distances are likely to evolve in natural landscapes (Hovestadt et al., 2001).

Empirical studies of plant spread have employed power laws to describe wind dispersal of seeds over relatively small spatial scales (e.g. Marco et al., 2011), but have not addressed larger scale patterns that may result from the power law behaviour of human or animal vectors. Scaling up from local dispersal models to those which are applicable across spatial scales is one of the key difficulties in dispersal ecology and requires alternative approaches to those used on small scales (Bullock \& Nathan, 2008).

Organisms which spread more rapidly than predicted by classical diffusion are referred to as having super-diffusive properties. One explanation for super-diffusive spread which has garnered much interest in recent scientific literature is the Lévy flight paradigm (Klafter \& Sokolov, 2005; Viswanathan, 2010). Lévy flights are characterised by a power law distribution in the occurrence of long-distance dispersal events, the probability $P(\ell)$ of a given dispersal step length $(\ell)$ occurring is $\approx \ell^{-\mu}$ and the exponent $\mu$ is $>1$ and $\leq 3$. Such Lévy flights predict super-linear rates of spread and have been shown to apply to populationlevel movements of humans on land (Brockmann et al., 2006; González et al., 2008), cargo ship movements (Kaluza et al., 2010), and the foraging movements of diverse wild animals (Sims et al., 2008; Bartumeus et al., 2010; Humphries et al., 2010).

$$
\text { Human activities are suggested to be the most important long distance vector for plants }
$$
and animals (Nathan, 2006), with human transport playing a central role in invasion for many species (Catford et al., 2009). Humans have been implicated as a principal long-distance dispersal vector in the spread of both marine and freshwater invasive species. Marine algae are commonly introduced to new regions by maritime traffic and aquaculture, while fishing gear is also likely to influence spread within regions (Williams \& Smith, 2007). Freshwater 
plants are most commonly introduced through the horticultural trade and may be inadvertently transported on boats or equipment (Keller et al., 2009). However, natural longdistance transportation of some marine species (most notably, in this study, Codium fragile, Colpomenia peregrina, Sargassum muticum) may occur by flotation without human aid, and avichory of seeds or vegetative propagules may also be an alternative long-distance vector for some species (e.g. Azolla filiculoides and Lemna minuta).

Whilst long-distance dispersal is a crucial component in estimating the spread of species (Kot et al., 1996; Higgins \& Richardson, 1999; Cain et al., 2000; Clark et al., 2003), it is notoriously difficult to quantify directly (Cain et al., 2000; Higgins et al., 2003) and remains a major challenge in invasion ecology (Hastings et al., 2005). This is mainly due to practical difficulties in quantifying rare dispersal events over large geographic areas using seed trapping and mark-recapture techniques. Genetic techniques, including parentage analysis, assignment methods and genealogical approaches have been applied successfully to dispersal kernel estimation (Cain et al., 2000); however, such studies are very labour intensive and many statistical methods are still in development. In addition, these methods are of limited use in the case of introduced species with high levels of clonality, including many freshwater plants, such as those in this study. Conversely, for many invasive species there is a wealth of historical geographic records data available.

We present a simulation model to examine the validity of using historical data to reconstruct step-length distribution patterns (i.e. dispersal kernels). Specifically, we examined whether it was possible to distinguish between alternative step-length distributions patterns; exponential, representing thin-tailed dispersal processes; and the Lévy distribution with a power-law tail (also termed Truncated Pareto) representing fat-tailed dispersal processes. 
We test the hypothesis that the Lévy flight step-length patterns are evident in the dispersal patterns of aquatic invasive species across spatial scales, using a historical dataset on freshwater and marine invasions, at three spatial scales: open ocean (North-East Atlantic), enclosed sea (Mediterranean) and an island environment (Ireland). This empirical dataset covers a range of species, 5 freshwater and 10 marine algae, which include a wide range of sizes (from less than $<3 \mathrm{~mm}$ (Lemna minuta) to $>3 \mathrm{~m}$ (Undaria pinnatifida) in length), reproductive traits and human uses including horticulture, food and aquaria planting (see Supplementary material, Table 1). Finally, the rates of range expansion of each species were examined to determine the link between fat-tailed (Lévy) step-length patterns and non-linear super-diffusive spread.

\section{Methods}

\section{Collation of records}

We collated a database of location records for the five most common invasive freshwater plant species in Ireland; namely Azolla filiculoides, Elodea canadensis, Lagarosiphon major, Elodea nuttallii and Lemna minuta $(n=2993)$ (Table 1, Supplementary material Fig. 1), spanning 171 years from 1836 to 2007. More than $98 \%$ of records were at a precision of 1 $\mathrm{km}$ or less, the remaining records were recorded at a precision of $10 \mathrm{~km}$. In addition we used location records of invasive marine algae from an extensive dataset (Mineur et al., 2010). Species were chosen for inclusion on the basis of having a sufficient number of records (> 50) (see Clauset et al. 2009) and being readily identifiable. Generalist habitat requirements and the widespread availability of suitable habitat across the study region were considered to be essential criteria for species inclusion. We selected ten of the most common invasive marine algae in the Mediterranean and European North Atlantic regions from this dataset for inclusion in this study namely Asparagopsis armata, Antithamnionella elegans, 
Antithamnionella ternifolia, Codium fragile, Colpomenia peregrina, Caulerpa taxifolia,

Dasysiphonia sp., Sargassum muticum, Undaria pinnatifida and Womersleyella setacea $(n=$ 1571) (Table 1, Supplementary material Figs. 2 and 3), spanning 153 years from 1853 to 2006. Location data were provided in WGS 1984 format to a precision of 4 decimal places. All location records were assumed positive at all dates after first recording.

\section{Dispersal step-length distributions}

We measured dispersal step-length distances of freshwater species as the shortest Euclidean distance from each new record to a previous record of the same species. This is likely to provide a conservative estimate of long distance dispersal, as some individuals may have dispersed from more distant populations. Further, we used Euclidean distances rather than distances by water as human movements over land have been previously shown to be a common vector for invasive freshwater species (Buchan \& Padilla, 1999). In our study we also found that many new records of our freshwater species were not connected by waterways, and therefore it was feasible and logical to assume that transportation had occurred across land. In this sense, Ireland is unusual in European terms in that major catchments are not usually connected by canals. We included all records of each species, except E. canadensis, which had spread to more than $90 \%$ of the region within 151 years, hence only the first 150 years of records were used representing the initial colonisation period. We calculated distances between marine species records as the shortest distance by sea (i.e. without crossing land). For eight of the eleven marine datasets, we calculated distances between records using the Pathmatrix 1.1 (Ray, 2005) extension for ArcGIS 3.2. These records were converted from WGS 1984 to the projected coordinate system ETRS 32 UTM (zone 32N) prior to distance calculations. We calculated distances between records for 172 the remaining three marine species (A. armata, C. fragile and S. muticum) in R 12.2.2 using 
the 'gdistance' package, due to computational constraints on large datasets in the Pathmatrix package. Distances for these species were calculated using a 0.02 degree cell raster grid. Inaccuracies in distance measurements arising from WGS 1984 were corrected for using the geocorrection function within the 'gdistance' package.

\section{Dispersal step-length analysis}

We used Maximum Likelihood Estimation (MLE) to fit power law, truncated power law (truncated Pareto) and exponential distributions to the dispersal step-length distribution of each species. The methodology employed here is described in detail in Humphries et al. (2010). Briefly, we used an iterative method in each case to derive the best fitting value for the remaining parameters (i.e. $x_{\min }$ for power law and exponential, and $x_{\min }$ and $x_{\max }$ for truncated Pareto). This resulted in reduced datasets in each case which included only the data that the distribution was deemed to fit. To enable robust model selection, MLE was used to fit each alternative, competing distribution to each reduced dataset (e.g. exponential and Pareto in the case of best-fitted truncated Pareto dataset) from which log-likelihoods and Akaike’s Information Criteria weights (wAIC) could then be calculated. The analysis of each data set therefore resulted in four pairs of wAIC: two pairs for the best fitting truncated power law vs. exponential (and vice versa) and two pairs for the best fitting exponential vs. power law (nontruncated) and vice versa.

We initially categorised datasets as Lévy or exponential based on the wAIC of the best fitting exponential vs. truncated Pareto and best fitting truncated Pareto vs. exponential. Where one model was the best fit in both tests, that model was considered best for the dataset. In some cases, the exponent of the truncated Pareto distribution was $<1$ (i.e. outside the Lévy range), so it was not possible to calculate the log-likelihood or wAIC. In other cases there was a conflict between the wAIC results of the two tests and the best fitting exponential 
vs. power law (non-truncated) was compared with the best fitting power law (non-truncated) vs. exponential results. If the exponential model performed better than the power law in both tests, the dataset was deemed to be exponential. All other datasets were considered unclassified, as they could not be assigned to either Lévy or exponential step-length distributions with confidence.

An underlying assumption of random walk analyses is that there is no strong relationship between the frequency distribution of step-length distances and time (e.g. that the pattern is not arising as the result of a few long-distance transport events at the end of a time-series characterised by short step-lengths). To ensure that this was not the case here, we visually assessed the pattern of step-lengths against time (see Supplementary, Fig. 4), and conducted a Spearman’s rank correlation test on step-length distances (standardised by species mean and standard deviation) against time. The correlation between step-length distance and time was very low (rho $=-0.073$ ), indicating no strong relationship between step-length and time in this dataset.

\section{Simulation model}

To our knowledge, the Lévy flight framework has not been previously applied to empirical data on the dispersal of plants, or indeed to movement networks inferred from maps detailing historical invasion patterns. To explore the validity of the method we developed a simulation environment to generate records of historic invasion. Specifically, our simulation tested whether assigning dispersal distances based on the closest previous invasion record reproduced the original dispersal kernel with sufficient accuracy to distinguish between Lévy flight (fat-tailed) and exponential (thin-tailed) dispersal patterns. Simulations were applied in R 12.2.2. 
Our models simulated the spread of a hypothetical invasive species based on alternative

223

224

225 movement patterns of vectors (exponential and power law). The model was applied within the terrestrial boundary of Ireland (as used in the empirical study of freshwater invasions). The mean values of fitted power-law and exponential distributions in the empirical freshwater species datasets were used as prior parameters for candidate distributions. Initially, the simulation generated a random point of introduction, after which, the spread of propagules was simulated from that location. The number of new propagules at each point was drawn from a Poisson distribution. The Poisson distribution had a mean of 1.5 new records per source point, which was the mean number of the new records occurring in the first ten years after introduction in the freshwater study species. This was repeated for five 'generations' (sufficient to recreate the number of records typical within historic records), with propagules 'reproducing' from every novel 'invasion point' created in the previous 'generation'. The direction of travel followed by each propagule varied randomly. The dispersal distance travelled by each new propagule was drawn from two alternative distributions depending on the process being simulated, namely an exponential distribution (rate $=0.07$ ) representing a Brownian-type diffusion process, or a power-law distribution $\left(x_{\min }=0.49\right.$, exponent $\left.=1.26\right)$ representing the Lévy model. Each simulation model was run 100 times. The mean number of resulting points per model was $163($ s.d. $=124)$.

The resulting simulated invasion data were treated and analysed in exactly the same manner as the empirical freshwater datasets (i.e. dispersal distances were estimated based on the shortest Euclidean distance to a previous point, and dispersal step-lengths were analysed in the same way). In addition, we compared the mean exponents of resulting best fitting distributions with those used in the construction of the simulation to assess whether these could be accurately estimated from the resulting simulated distribution map. 


\section{Rates of spread}

248 We calculated the 'invaded area' of each empirical species as the convex hull containing all records of the species at each time point. Convex hulls were calculated using the Geospatial Modelling Environment version 0.5.3 Beta (Hawthorne, 2011) and ArcGIS 10. Convex hulls were clipped to the available range (i.e. land mass of Ireland for freshwater species, sea for marine species) using ArcGIS. Spread rates were defined as the increase in the square root of the area within the 'invaded area' over time.

We then fitted linear, 2 parameter exponential and 3 parameter sigmoidal functions to spread rates (square root of 'invaded area' as a function of time since introduction) by MLE. We compared the fits of these three functions using Akaike Information Criteria corrected for small sample sizes (AICc) and corresponding AICc. Linear spread rates represented expected spread under classical reaction diffusion. Initial super-linear rates characteristic of anomalous diffusion were represented by an exponential curve (i.e. continuously accelerating spread) and a sigmoid curve (i.e. initial accelerating spread followed by a decline in spread rate). This represents the common scenario in natural systems where the observed expansion rate slows as the maximum available range is approached (Mack et al., 2000). Equation fitting and model comparison were conducted in R 12.2.2 (R Development Core Team, 2011) and plotted with SigmaPlot 10 (Systat, 2010).

\section{Results}

\section{Simulation analysis}

The rate of false positives was $1 \%$ (i.e. datasets created from an exponential dispersal distribution that were incorrectly assigned to the Lévy model or vice versa). The rate of true 
remaining $16.5 \%$ of cases, results were ambiguous and it was not possible to assign them to either distribution (Supplementary material Table 2). In the empirical data, these were treated as unclassified, as it was unclear whether species had Lévy or exponential dispersal kernels. Additionally, the fitted truncated Pareto (power law) distributions provided a good approximation of the $x_{\min }$ and exponents used to simulate dispersal patterns. In Lévy (truncated Pareto) based simulations the estimated mean exponent of $1.27($ s.d. $=0.43$ ) (generated from 1.26) and the estimated mean $x_{\min }$ of $0.431(\mathrm{sd}=0.13)$ (generated from 0.49) recovered the modelled dispersal pattern reasonably well. In exponential based simulations, the estimated mean rate was 0.24 (s.d. 0.07) (generated from 0.07), suggesting that the method of assigning dispersal distances may under-estimate the amount of long-distance dispersal occurring when the real dispersal step-length distribution is exponential. Despite this, the low rate of false positives indicates that the method is useful for distinguishing between historical distribution patterns arising from Lévy (fat-tailed) and exponential (thintailed) dispersal step-length distributions.

\section{Dispersal step-length analysis}

Three of the five freshwater species were fitted best by the truncated power law and showed exponents within the Lévy range (mean exponent, $1.38 \pm 0.15$ s.d.). One species, Lemna minuta, was fitted best by an exponential, while Lagarosiphon major could not be reliably fit best by either model (Table 2, Fig. 2). In eight of the eleven invasions of marine algae, dispersal distributions were fitted best by the truncated power law with exponents within the Lévy range (mean, $1.20 \pm 0.16$ s.d.). Three species (Antithamnionella ternifolia, Dasysiphonia sp. and Undaria pinnatifida) were not reliably fit best by either model (Table 2, Fig. 2). Maximum step lengths for individual species were between $141 \mathrm{~km}$ and $275 \mathrm{~km}$ in 
297

298

299

300

301

302

303

304

305

306

307

308

309

310

311

312

313

314

315

316

317

freshwater species, and $614 \mathrm{~km}$ and $2012 \mathrm{~km}$ in marine species, suggesting that population establishment after long-distance dispersal events occurs for all study species across habitats (Table 2).

\section{Rates of spread}

Sigmoid curves fit best to the spread rates of the freshwater invasive species - A. filiculoides and E. nuttallii, and an exponential fit best for E. Canadensis, consistent with the finding of Lévy dispersal distributions for these species. L. major and L. minuta were fitted best by linear spread rates consistent with classical reaction diffusion, although the sigmoidal model had some support for L. minuta. In the marine algae, 9 of the 11 spread rates were non-linear (sigmoidal) (Table 3, Fig. 3). Overall, the analysis showed that the vast majority of species had a Lévy distribution of step lengths and exhibited non-linear, initially accelerating spread rates. The spread of Dasysiphonia sp. was linear and did not show a Lévy pattern (Fig. 2m). Interestingly, A. armata in the Mediterranean was best fitted by a linear spread model, despite its Lévy step-length pattern (Fig 2g, Fig. 3g): however the spread of this species was also well described by a sigmoidal curve (Table 3, Fig. 3g). 
319 In this study, we demonstrate through simulation that dispersal step-length distributions (dispersal kernels) of invasive species can be reconstructed from historical distribution data, and that the accuracy of this method is sufficient to differentiate between fat-tailed Lévy steplength dispersal distributions and thin-tailed exponential dispersal distributions. In the great majority of simulation runs, the dispersal distribution used in the model input could be inferred from the spatial pattern of location records outputted by the simulation. The Lévy framework, and especially the use to step-length analysis, is an increasingly common tool used to examine ecological and behaviour processes. Here, it is shown that it can be extended to explore the processes of range expansion and colonisation over both protracted time periods and large spatial scales to extract generalised patterns of invasion biology.

Lévy dispersal patterns were detected in the majority of study species, despite differences in size, reproductive traits and human uses of species. This suggests that Lévy dispersal patterns may be common amongst aquatic plants and algae. dispersal and linear spread. L. minuta differs from the other freshwater species in that individual plants are very small $(<3 \mathrm{~mm})$ and unlikely to be intentionally transported by humans for ornamental or aquaculture purposes. L. major belongs to the same family as Elodea nuttallii and Elodea canadensis and has a very similar morphology and association with human trade. However, L. major differs from these species in that it is associated with alkaline conditions: in Ireland $71 \%$ of its recorded distribution is within one lake system (Lough Corrib, Co. Galway). Therefore, the recorded distribution of this species may reflect the availability of this specialized habitat, rather than purely the dispersal dynamics of its vectors. 
In eight of the 11 invasions of marine algae, showed Lévy dispersal patterns and seven

344 of these showed concordant sigmoidal non-linear spread. Only one marine species showed a solely linear range expansion (Dasysiphonia sp.). This species showed no evidence of a Lévy step-length distribution pattern. While some long-distance jump dispersal events early in the spread of this species have been documented (Mineur et al., 2010), these are not as frequent as would be expected in a Lévy spread pattern. The contrast between the linear spread of Asparagopsis armata in the Mediterranean and the sigmoidal spread in the Atlantic is interesting given that it exhibited a Lévy step length distribution in both regions. The cause of this disparity between regions is unclear, but it could result from multiple factors, including those associated with community dynamics, algal life-history traits and environmental conditions (Lyons \& Scheibling, 2009). Two further species (Antithamnionella ternifolia and Undaria pinnatifida) showed no evidence of Lévy patterns, but did have sigmoidal spread. In these cases, there may have been a higher frequency of long distance dispersal than predicted by an exponential model, but not as high as in Lévy models (Figs 2i, 2o).

This study has combined the previously observed high levels of long-distance dispersal in plant populations and invasion ecology with the developing framework of Lévy flight. Whilst the classification of Lévy flights has received significant recent attention in animal foraging ecology (González et al., 2008; Sims et al., 2007; Humphries et al., 2010, Lundy et al. 2012), their role in longer term species spread has received relatively little attention.

The super-diffusive patterns of invasive spread by freshwater plants and marine algae may arise as an emergent property of human translocations over land (Gonzalez et al. 2008), or by commercial shipping (Kaluza et al. 2010) on hulls or in ballast water. Previous studies have suggested a correlation between invasive species human factors such as trade, travel (Catford et al., 2009), population density and gross national product (Keller et. al, 2009). Trends in the 
trade of particular commodities (e.g. aquaculture plants) are also likely to correlate with the rate spread of species (Hulme et al. 2009).

Previous studies have reported maximum dispersal distances by non-human transport for plants of 1-20 km (Cain et al., 2000), thus corroborating the likelihood that extreme longdistance transport may be attributable to human transport. However, avichory (seed dispersal by birds) cannot be dismissed as a candidate non-human vector. The seeds of many freshwater aquatic plants remain viable after transport in the intestines of wildfowl and this may account for dispersal over hundreds of kilometres (Brochet et al., 2010). However, more than half of the freshwater species in the current study reproduced by vegetative means only may, therefore, increase rates of spread of these species. However, as we found no correlation further supporting the role of humans as the key long-distance vector.

$$
\text { Increases in human trade and transportation during the present period of globalisation }
$$
between step-length distances and year, we suggest that this results from the frequency of introductions, rather than changes in the relative frequency of long-distance transport. However, as this study only investigates European invasion patterns we can not comment on larger global scale patterns between continents.

Furthermore, species traits are likely to influence the extent to which particular organisms can benefit from long-distance dispersal opportunities (Theoharides \& Dukes, 2007; van Kluenen et al., 2010). For example, the rare super-diffusive movements of Lévy flight are likely to be of most benefit to organisms that can establish new populations from single introductions, such as, self-fertile and asexually reproducing taxa (e.g. clonal plants and many plant pests (e.g. Ash disease Chalara fraxinea), and those with short generation times are ideally suited to this condition. 

populations, is best suited to species with generalist habitat requirements and those species for which suitable habitat is available across the region at the spatial scale of the study, such as generalist invasive species. In the case of specialist species, landscape heterogeneity is likely to confound observed patterns due to its role as a barrier to the establishment of species post-dispersal.

The identification of Lévy patterns does not necessarily imply the existence of a Lévy movement process. It is possible that the observed Lévy patterns arise as the result of a combination of vectors, or vector behaviour, operating at different scales, consistent with the observations of a Lévy distribution of displacements being present at the population-level in human mobility patterns (Brockmann et al. 2006; Gonzalez et al. 2008, Petrovskii et al., 2011). Similarly, short distance dispersal might be explained by water or wind dispersal, middistance by mammals and wind, and long distance by bird or human transport. formulation of strategic management plans in invasion biology. This study shows that fattailed dispersal patterns with high rates of long-distance dispersal can be inferred from historical data, and occur frequently in aquatic invasive species across large spatial scales. High rates of long-distance dispersal frequently lead to accelerating spread rates (Higgins \& Richardson, 1999), increase the difficulty of predicting where invasions will occur next in a landscape (Clark et al., 2003) and may overwhelm the role of life history and landscape heterogeneity in determining rates of spread (Marco et al., 2011). The identification of these patterns in these species emphasizes the importance of focusing management not only on short-distance movements, but also on rarer long-distance vectors which increase uncertainty and cause rates of spread to accelerate, such as trade and transport. 


\section{Acknowledgements}

417 This research was funded by the Natural Heritage Research Partnership (NHRP) between the

418 Northern Ireland Environment Agency (NIEA) and Quercus, Queen’s University Belfast

419 (QUB) under a PhD studentship (QU08-05). Many thanks to the Client Officer, John Early,

420 for his support. Thanks also to the Botanical Society of the British Isles (BSBI); the Centre

421 for Environmental Data and Recording (CEDaR); Invasive Species Ireland (ISI); the National

422 Data and Recording Centre (NDRC); the National Biodiversity Network (NBN) Gateway and

423 the Northern Ireland Environment Agency (NIEA) for providing distributional data. D.W.S.

424 and N.E.H. were supported by the UK Natural Environment Research Council Oceans 2025

425 Strategic Research Programme (Theme 6) in which D.W.S. is a principal investigator. F.M.

426 was partly funded by a grant from the AXA Foundation. We would also like to thank our

427 two anonymous reviewers who provided valuable feedback on the manuscript. 


\section{References}

430

431 Bartumeus, F. et al. 2010. Fishery discards impact on seabird movement patterns at regional scales. - Curr. Biol. 20: 215-222

433

434

Beyer, H. L. 2001-2011 Geospatial Modelling Environment (C Spatial Ecology LLC.

435

436

Brockmann, D. et al. 2006. Scaling laws of human travel. - Nature 439: 462 - 465

437

438

439

440

Chapter: Brockmann, D. 2009. Human mobility and spatial disease dynamics. - In: Schuster, H. G. (ed), Reviews of nonlinear dynamics and complexity. Wiley-Vch: Weinheim, pp. 1-

441

442

443

Buchan, L. A. J. and Padilla, D. K. 1999. Estimating the probability of long-distance overland dispersal of invading aquatic species. - Ecol. App. 9: 254-265

444

445

Brochet, A. L. et al. 2010. Plant dispersal by teal (Anas crecca) in the Camargue: duck guts 446 are more important than their feet. - Freshwater Biol. 55: 1262-1273

447

448

449

Bullock, J. M. et al. 2008. Managing plant population spread: prediction and analysis using a simple model. - Ecol. Appl. 18: 945-953

450

451

Cain, M. L. et al. 2000. Long-distance seed dispersal in plant populations. - Am. J. Bot. 87:

452 1217-1227

453 
454 Clark, J. S. 1998. Why trees migrate so fast: confronting theory with dispersal biology and 455 the paleorecord. - Am. Nat. 152: 204-224

456

457 Clark, J. S. et al. 2003. Estimating Population Spread: What Can We Forecast and How

$458 \quad$ Well? - Ecology 84: 1979-1988

459

460 Catford, J. A. et al. 2009. Reducing redundancy in invasion ecology by integrating

461 hypotheses into a single framework. - Divers. Distrib. 15: 22-40

462

463 Clauset, A. et al. 2009. Power-law distributions in empirical data. - SIAM Review 51: 661$464 \quad 703$

465

466

467

González, M. C. et al. (2008) Understanding individual human mobility patterns. - Nature

468

469

470

Hastings, A. et al. 2005. The spatial spread of invasions: new developments in theory and evidence. - Ecol. Lett. 8: 91-101

471

472

Higgins P. A. T. and Harte, J. 2006. Biophysical and biogeochemical responses to climate 473 change depend on dispersal and migration. - Bioscience 56: 407-417

474

475 Higgins, S. I. and Richardson, D.M. 1999. Predicting plant migration rates in a changing $476 \quad$ world: the role of long-distance dispersal. - Am. Nat. 153: 464-475

477 
478 Hovestadt, T. et al. 2001. Evolution of reduced dispersal mortality and 'fat-tailed' dispersal 479 kernels in autocorrelated landscapes. - P. R. Soc. B. 268: 385-391

480

481 Hufnagel, L., et al. 2004. Forecast and control of epidemics in a globalized world. - P. Natl. $482 \quad$ Acad. Sci. USA 101: 15124-15129

483

484 Hulme, P. E. 2009. Trade, transport and trouble: managing invasive species pathways in an 485 era of globalization. - J. Appl. Ecol. 46: 10-18

486

487

488

Humphries, N. E. et al. 2010. Environmental context explains Lévy and Brownian movement patterns of marine predators. - Nature, 465: 1066 - 1069

489

490

Kaluza, P. et al. 2010. The complex network of global cargo ship movements. - P. R. Soc.

491 Interface 7: 1093-1103

492

493

Keller, R. P et al. 2009. Vectors and timing of freshwater invasions in Great Britain. 494 Conserv. Biol. 23: 1526-1534

495

496

497

Kilpatrick, A. M. 2011. Globalization, land use, and the invasion of West Nile virus. -

498

499

Klafter, J. and Sokolov, I. M. 2005 Anomalous diffusion spreads its wings. - Phys. World, 500 18: $29-32$

501 
502

503

504

505

506

507

508

509

510

511

512

513

514

515

516

517

518

519

520

521

522

523

524

525

526

Kot, M. et al. 1996. Dispersal data and the spread of invading organisms. - Ecology 77: 2027-2042

Lundy, M. G., Harrison, A., Buckley, D.J., Boston, E. S., Scott, D. D., Teeling, E.C., Montgomery W. I. and Houghton, J.D.R. 2012. Prey field switching based on preferential behaviour can induce Lévy flights. - J R Soc Interface. 10: 20120489

Lyons, D. A. and Scheibling, R. E. 2009. Range expansion by invasive marine algae: rates and patterns of spread at a regional scale. - Divers. Distrib. 15: 762-775

Mack, R. N. et al. 2000. Biotic invasions: causes, epidemiology, global consequences and control. - Ecol. Appl. 10: 689-710

Marco, D. E. et al. 2011 Comparing short and long-distance dispersal: modelling and field case studies. - Ecography 34: 671-682

Mineur, F. et al. (2010) Fronts, jumps and secondary introductions suggested as different invasion patterns in marine species, with increase in spread rates over time. - P. R. Soc. B., 277: 2693-2701

Mundt, C. C. et al. 2009. Long-distance dispersal and accelerating waves of disease: empirical relationships. - Am. Nat. 173: 456 - 466

Nathan, R. 2006 Long-distance dispersal of plants. - Science, 313: 786-788 
527 Nathan, R. et al. 2008. A movement ecology paradigm for unifying organismal movement 528 research. - P. Natl. Acad. Sci. USA 105: 19052 - 19059

529

530 Petrovskii, S. V. et al. 2011. Variation in individual walking behavior creates the impression 531 of a Lévy flight. - P. Natl. Acad. Sci. USA 108: 8704-870

532

533

534

R Development Core Team 2011. R: A language and environment for statistical computing. R Foundation for Statistical Computing, Vienna, Austria.

535

Ray N. 2005. PATHMATRIX: a GIS tool to compute effective distances among samples. Mol. Ecol. Notes 5: 177-180

538

539

Shigesada, N. et al. 1995 Modelling stratified diffusion in biological invasions. - Am. Nat.

540 146: $229-251$

541

542

543

Sims, D. W. et al. 2008. Scaling laws of marine predator search behaviour. - Nature 451: 1098-1102

544

545

Skellam, J. G., 1951 Random dispersal in theoretical populations. - Biometrika 38: 196-218 546

Strayer, D. L. 2010. Alien species in fresh waters: ecological effects, interactions with other 548 stressors, and prospects for the future. - Freshwater Biol. 55: 152-174

549

550

Systat Software Inc. 2012. Sigma Plot 10

551 
552 Theoharides, K. A., and Dukes, J. S. 2007 Plant invasion across space and time: factors 553 affecting nonindigenous species success during four stages of invasion. - New Phytologist $554 \quad 176: 256-273$

555

556 Viswanathan, G. M. 2010. Ecology: Fish in Lévy-flight foraging. - Nature, 465: 1018-1019

557

558 Viswanathan, G. M. et al. 2011. The Physics of Foraging: An Introduction to Random

559 Searches and Biological Encounters. Cambridge University Press: Cambridge

560

561 Williams, S. L. and Smith, J. E. 2007. A global review of the distribution, taxonomy, 562 and impacts of introduced seaweeds. - Annu. Rev. Ecol. Evol. S. 38: 327-59

563

564 Williamson, M. et al. 2005. On the rates and patterns of spread of alien plants in the Czech 565 Republic, Britain, and Ireland. - Ecoscience 12: 424-433

566

567 Yamamura, K. et al. 2006. Estimation of the potential speed of range expansion of an 568 introduced species: characteristics and applicability of the gamma model. - Popul. Ecol. 49:

$569 \quad 51-62$

570

571 


\section{Tables}

573

574 Table 1. Dates of introduction, number of records, region and prevalence of study species.

575 MCP denotes minimum convex polygon.

\begin{tabular}{llcccr}
\hline Habitat & Species name & $\begin{array}{c}\text { Number of } \\
\text { records }\end{array}$ & $\begin{array}{c}\text { Year of } \\
\text { introduction }\end{array}$ & Region & $\begin{array}{c}\text { Invasive range } \\
\text { MCP (sq. km) }\end{array}$ \\
\hline Freshwater & Azolla filiculoides & 168 & 1893 & Ireland & 52,004 \\
& Elodea canadensis & 2,348 & 1836 & Ireland & 73,952 \\
& Elodea nuttallii & 201 & 1970 & Ireland & 52,753 \\
& Lagarosiphon major & 147 & 1966 & Ireland & 66,136 \\
& Lemna minuta & 129 & 1987 & Ireland & 50,072 \\
\hline Marine & Asparagopsis armata & 155 & 1923 & Atlantic & 623,170 \\
& Asparagopsis armata & 118 & 1923 & Mediterranean & $1,237,195$ \\
& Antithamnionella elegans & 67 & 1882 & Mediterranean & $2,163,856$ \\
& Antithamnionella ternifolia & 80 & 1906 & Atlantic & 658,072 \\
& Codium fragile & 207 & 1845 & Atlantic & $1,345,940$ \\
& Colpomenia peregrine & 104 & 1905 & Atlantic & $1,350,104$ \\
& Caulerpa taxifolia & 86 & 1984 & Mediterranean & 628,499 \\
& Dasysiphonia sp. & 54 & 1994 & Atlantic & 997,160 \\
& Sargassum muticum & 544 & 1972 & Atlantic & $1,210,447$ \\
& Undaria pinnatifida & 87 & 1982 & Atlantic & 253,584 \\
& Womersleyella setacea & 69 & 1987 & Mediterranean & $1,191,008$ \\
\hline
\end{tabular}


576 Table 2. Summary of the empirical data and results of MLE fitted to dispersal step lengths, showing best fit parameters and model comparison 577 analysis wAIC. TP and Exp denote truncated Pareto (power law) and exponential models respectively. U is where neither model reliably accounted for the data. TP wAIC is given as NA when TP exponent <1 (outside Lévy range).

579

\begin{tabular}{|c|c|c|c|c|c|c|c|c|c|}
\hline Species & $\mathbf{N}$ & $\begin{array}{c}\text { Min Step } \\
\text { Length (km) }\end{array}$ & $\begin{array}{c}\text { Max step } \\
\text { length (km) }\end{array}$ & $\begin{array}{c}\text { Best fitting } \\
\text { distribution }\end{array}$ & $\begin{array}{c}\text { Best fit } \\
\text { exponent }\end{array}$ & $\begin{array}{l}\text { Best fit } \\
\text { X-min }\end{array}$ & $\begin{array}{l}\text { Best fit } \\
\text { X-max }\end{array}$ & $\operatorname{Exp}$ AIC w & TP AIC w \\
\hline Azolla filiculoides & 135 & $<0.1$ & 191 & $\mathrm{TP}$ & 1.54 & 0.99 & 191.70 & $<0.01$ & 1.00 \\
\hline Elodea canadensis & 261 & $<0.1$ & 275 & $\mathrm{TP}$ & 1.36 & 0.49 & 59.46 & $<0.01$ & 1.00 \\
\hline Elodea nuttalli & 178 & 0.1 & 218 & $\mathrm{TP}$ & 1.23 & 0.14 & 218.41 & $<0.01$ & 1.00 \\
\hline Lemna minuta & 124 & 0.1 & 220 & $\mathrm{E}$ & 0.07 & 0.05 & 220.62 & 1.00 & NA \\
\hline Lagarosiphon major & 119 & 0.1 & 141 & $\mathrm{U}$ & 0.02 & 0.10 & 141.61 & 1.00 & NA \\
\hline Asparagopsis armata (Atl) & 118 & 1.0 & 1390 & $\mathrm{TP}$ & 1.09 & 3.83 & 298.28 & $<0.01$ & 1.00 \\
\hline Asparagopsis armata (Med) & 155 & 1.2 & 1255 & $\mathrm{TP}$ & 1.21 & 1.24 & 345.07 & $<0.01$ & 1.00 \\
\hline Antithamnionella elegans & 67 & 1.4 & 2032 & $\mathrm{TP}$ & 1.17 & 2.41 & 2032.68 & $<0.01$ & 1.00 \\
\hline Antithamnionella ternifolia & 80 & 0.3 & 1300 & $\mathrm{U}$ & 0.004 & 79.01 & 1300.83 & 0.51 & 0.49 \\
\hline Codium fragile & 207 & 1.1 & 865 & $\mathrm{TP}$ & 1.03 & 1.20 & 312.56 & $<0.01$ & 1.00 \\
\hline Colpomenia peregrina & 104 & 0.1 & 853 & $\mathrm{TP}$ & 1.01 & 10.66 & 470.27 & $<0.01$ & 1.00 \\
\hline Caulerpa taxifolia & 86 & 1.0 & 834 & $\mathrm{TP}$ & 1.34 & 2.00 & 258.57 & $<0.01$ & 1.00 \\
\hline Dasysiphonia sp. & 54 & 0.2 & 1015 & $\mathrm{U}$ & 0.003 & 49.73 & 1015.23 & 1.00 & NA \\
\hline Sargassum muticum & 544 & 1.4 & 612 & $\mathrm{TP}$ & 1.40 & 1.38 & 262.70 & 0.00 & 1.00 \\
\hline Undaria pinnatifida & 87 & 1.0 & 805 & $\mathrm{U}$ & 0.01 & 16.07 & 805.68 & 0.55 & 0.45 \\
\hline Womersleyella setacea & 69 & 0.5 & 2014 & $\mathrm{TP}$ & 1.35 & 12.66 & 1157.64 & $<0.01$ & 1.00 \\
\hline
\end{tabular}


581 Table 3. Model fit of curves describing rates of range expansion and colonisation. $\mathrm{n}=$

582 number of years in which invasion range increased. Grey shading highlights the best fitting

583 function for each species.

584

\begin{tabular}{|c|c|c|c|c|c|c|}
\hline Habitat & Species & $\mathbf{n}$ & Function & AICc & $\Delta \mathrm{AIC}$ & $\% \omega_{i}$ \\
\hline \multirow[t]{15}{*}{ Freshwater } & \multirow[t]{3}{*}{ Azolla filiculoides } & \multirow[t]{3}{*}{24} & Linear & 251.73 & 44.08 & 0 \\
\hline & & & Exponential & 248.91 & 41.26 & 0 \\
\hline & & & Sigmoidal & 207.65 & 0.00 & 100 \\
\hline & \multirow[t]{3}{*}{ Elodea canadensis } & \multirow[t]{3}{*}{36} & Linear & 314.86 & 22.58 & 0 \\
\hline & & & Exponential & 292.29 & 0.00 & 77 \\
\hline & & & Sigmoidal & 294.65 & 2.36 & 23 \\
\hline & \multirow[t]{3}{*}{ Elodea nuttallii } & \multirow[t]{3}{*}{16} & Linear & 153.89 & 17.87 & 0 \\
\hline & & & Exponential & 153.14 & 17.12 & 0 \\
\hline & & & Sigmoidal & 136.02 & 0.00 & 100 \\
\hline & \multirow[t]{3}{*}{ Lagarosiphon major } & \multirow[t]{3}{*}{15} & Linear & 123.82 & 0.00 & 96 \\
\hline & & & Exponential & 142.55 & 18.74 & 0 \\
\hline & & & Sigmoidal & 130.20 & 6.39 & 4 \\
\hline & \multirow[t]{3}{*}{ Lemna minuta } & \multirow[t]{3}{*}{13} & Linear & 102.12 & 0.00 & 53 \\
\hline & & & Exponential & 105.58 & 3.42 & 9 \\
\hline & & & Sigmoidal & 102.79 & 0.67 & 37 \\
\hline \multirow[t]{30}{*}{ Marine } & \multirow[t]{3}{*}{ Asparagopsis armata (Atl) } & \multirow[t]{3}{*}{21} & Linear & 266.85 & 22.28 & 0 \\
\hline & & & Exponential & 274.75 & 30.17 & 0 \\
\hline & & & Sigmoidal & 244.58 & 0.00 & 100 \\
\hline & \multirow[t]{3}{*}{ Asparagopsis armata (Med) } & \multirow[t]{3}{*}{16} & Linear & 282.71 & 0.00 & 58 \\
\hline & & & Exponential & 296.49 & 4.92 & 5 \\
\hline & & & Sigmoidal & 207.68 & 0.87 & 37 \\
\hline & \multirow[t]{3}{*}{ Antithamninonella elegans } & \multirow[t]{3}{*}{15} & Linear & 219.03 & 23.50 & 0 \\
\hline & & & Exponential & 206.46 & 10.93 & 0 \\
\hline & & & Sigmoidal & 195.53 & 0.00 & 100 \\
\hline & \multirow[t]{3}{*}{ Antithamnionella ternifolia } & \multirow[t]{3}{*}{14} & Linear & 165.55 & 4.12 & 11 \\
\hline & & & Exponential & 179.34 & 17.91 & 0 \\
\hline & & & Sigmoidal & 161.43 & 0.00 & 89 \\
\hline & \multirow[t]{3}{*}{ Codium fragile } & \multirow[t]{3}{*}{28} & Linear & 342.16 & 21.69 & 0 \\
\hline & & & Exponential & NS & NA & NA \\
\hline & & & Sigmoidal & 320.47 & 0.00 & 100 \\
\hline & \multirow[t]{3}{*}{ Colpomenia peregrina } & 28 & Linear & 367.71 & 55.02 & 0 \\
\hline & & & Exponential & 384.11 & 71.42 & 0 \\
\hline & & & Sigmoidal & 312.69 & 0.00 & 100 \\
\hline & Caulerpa taxifolia & 8 & Linear & 109.27 & 11.36 & 0 \\
\hline & & & Exponential & 114.72 & 16.82 & 0 \\
\hline & & & Sigmoidal & 97.91 & 0.00 & 100 \\
\hline & Dasysiphonia sp. & 11 & Linear & 147.57 & 0.00 & 92 \\
\hline & & & Exponential & 152.53 & 4.96 & 8 \\
\hline & & & Sigmoidal & NS & NA & 0 \\
\hline & Sargassum muticum & 24 & Linear & 293.35 & 20.59 & 0 \\
\hline & & & Exponential & 315.34 & 42.58 & 0 \\
\hline & & & Sigmoidal & 272.76 & 0.00 & 100 \\
\hline & Undaria pinnatifida & 13 & Linear & 150.12 & 17.69 & 0 \\
\hline & & & Exponential & 162.66 & 30.24 & 0 \\
\hline & & & Sigmoidal & 132.43 & 0.00 & 100 \\
\hline
\end{tabular}



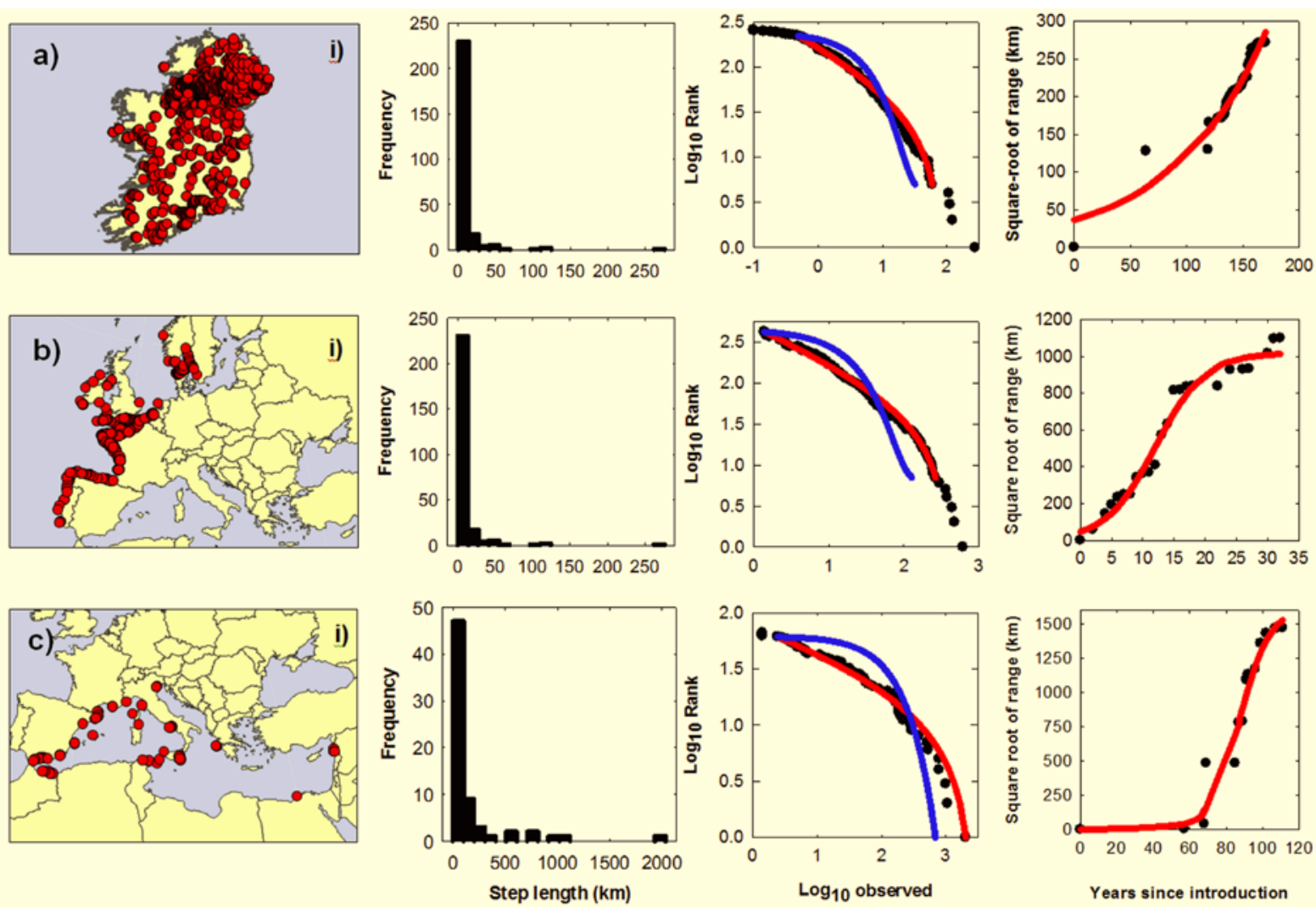

Figure 1 Super-diffusive invasion dynamics of freshwater plants and marine algae.

590 Geographical distributions of a, Elodea canadensis in Ireland, b, Sargassum muticum in the north-eastern Atlantic Ocean and c, Antithamnionella elegans in the Mediterranean Sea, each showing i) their geographical distributions, ii) a frequency histogram of invasion step lengths, iii) competing models showing best fit for a truncated Pareto function (red line) and an exponential function (blue line), and iv) non-linear spread based on the increase of the square root of the invaded area over time. 
597 Figure 2 Best fitting models to ranked step-length/frequency plots. Truncated power law 598 (TP) (red line) and exponential (E) (blue line) models to observed data (black circles), or 599 unclassified (U). For details of fitting results see Table 2. Best fit model given in parentheses 600 following species name. Freshwater species: (a) Azolla filiculoides (TP); (b) Elodea 601 canadensis (TP); (c) Elodea nuttallii (TP); (d) Lagarosiphon major (U); (e) Lemna minuta 602 (E). Marine species: (f) Asparagopsis armata (Atl) (TP); (g) Asparagopsis armata (med) 603 (TP); (h) Antithamnionella elegans (TP); (i) Antithamnionella ternifolia (U); (j) Codium 604 fragile (TP); (k) Colpomenia peregrina (TP); (l) Caulerpa taxifolia (TP); (m) Dasysiphonia 605 sp. (U); (n) Sargassum muticum (TP); (o) Undaria pinnatifida (U) and (p) Womersleyella 606 setacea $(\mathrm{TP})$. 
607

608 Figure 3 Spread rates of invasive species. Solid red line indicates best fitting model. Dashed 609 red line indicates second best model where $\Delta \mathrm{AICc}<2$. Freshwater species: (a) Azolla 610 filiculoides (sigmoidal); (b) Elodea canadensis (exponential); c) Elodea nuttallii (sigmoidal); 611 (d) Lagarosiphon major (linear); (e) Lemna minuta (linear(solid line)/sigmoidal(dashed 612 line)). Marine species: (f) Asparagopsis armata (Atl) (sigmoidal); (g) Asparagopsis armata 613 (med) (linear(solid line)/sigmoidal (dashed line)); (h) Antithamnionella elegans (sigmoidal); 614 (i) Antithamnionella ternifolia (sigmoidal); (j) Codium fragile (sigmoidal); (k) Colpomenia 615 peregrina (sigmoidal); (l) Caulerpa taxifolia (sigmoidal); (m) Dasysiphonia sp. (linear); (n) 
616 Sargassum muticum (sigmoidal); (o) Undaria pinnatifida (sigmoidal); (p) Womersleyella 617 setacea (sigmoidal).

618 


\section{Supplementary material}

Table 1 Names, size, reproductive traits and human uses of study species

\begin{tabular}{|c|c|c|c|c|}
\hline Scientific Name & Common name & $\begin{array}{l}\text { Maximum } \\
\text { height/length } \\
\text { (cm) }\end{array}$ & $\begin{array}{l}\text { Reproduction in } \\
\text { invaded European } \\
\text { range }\end{array}$ & $\begin{array}{l}\text { Human use in } \\
\text { invaded range }\end{array}$ \\
\hline \multicolumn{5}{|l|}{ Freshwater plants } \\
\hline Azolla filiculoides Lam. & A water fern & 5 & $\begin{array}{l}\text { Sexual (fern) and } \\
\text { vegetative } \\
\text { (fragmentation) }\end{array}$ & Ornamental \\
\hline Elodea canadensis Michx & $\begin{array}{l}\text { Canadensis } \\
\text { Pondweed }\end{array}$ & 300 & $\begin{array}{l}\text { Vegetative (stolons } \\
\text { and fragmentation) }\end{array}$ & $\begin{array}{l}\text { Ornamental in } \\
\text { horticulture and } \\
\text { aquaria }\end{array}$ \\
\hline $\begin{array}{l}\text { Elodea nuttallii (Planch.) } \\
\text { H St. John }\end{array}$ & $\begin{array}{l}\text { Nuttall's } \\
\text { Pondweed }\end{array}$ & 300 & $\begin{array}{l}\text { Vegetative (stolons } \\
\text { and fragmentation) }\end{array}$ & $\begin{array}{l}\text { Ornamental in } \\
\text { horticulture and } \\
\text { aquaria }\end{array}$ \\
\hline $\begin{array}{l}\text { Lagarosiphon major } \\
\text { (Ridl.) Moss }\end{array}$ & $\begin{array}{l}\text { Curly } \\
\text { Waterweed }\end{array}$ & 300 & $\begin{array}{l}\text { Vegetative (stolons } \\
\text { and fragmentation) }\end{array}$ & $\begin{array}{l}\text { Ornamental in } \\
\text { horticulture and } \\
\text { aquaria }\end{array}$ \\
\hline Lemna minuta Kunth & A duckweed & 0.3 & $\begin{array}{l}\text { Primarily vegetative } \\
\text { (budding), also sexual } \\
\text { (dioecious) }\end{array}$ & \\
\hline \multicolumn{5}{|l|}{ Marine algae } \\
\hline $\begin{array}{l}\text { Asparagopsis armata } \\
\text { Harvey }\end{array}$ & Harpoon Weed & 30 & $\begin{array}{l}\text { Sexual (dioecious), } \\
\text { vegetative } \\
\text { propagation abundant }\end{array}$ & \\
\hline $\begin{array}{l}\text { Antithamnionella elegans } \\
\text { (Berthold) J.H.Price \& } \\
\text { D.M.John }\end{array}$ & A red alga & 5 & $\begin{array}{l}\text { Sexual (dioecious), } \\
\text { vegetative } \\
\text { propagation abundant }\end{array}$ & \\
\hline $\begin{array}{l}\text { Antithamnionella } \\
\text { ternifolia (J.D.Hooker \& } \\
\text { Harvey) Lyle }\end{array}$ & A red alga & 5 & $\begin{array}{l}\text { Sexual (dioecious), } \\
\text { vegetative } \\
\text { propagation abundant }\end{array}$ & \\
\hline $\begin{array}{l}\text { Codium fragile } \\
\text { subspecies tomentosoides } \\
\text { (van Goor) P.C.Silva }\end{array}$ & $\begin{array}{l}\text { Green Sea } \\
\text { Fingers/ Dead } \\
\text { Man's Fingers }\end{array}$ & 50 & $\begin{array}{l}\text { Parthenogenetic } \\
\text { spores }\end{array}$ & \\
\hline $\begin{array}{l}\text { Caulerpa taxifolia (M. } \\
\text { Vahl) C. Agardh }\end{array}$ & Feather Caulerpa & 100 & Primarily vegetative & $\begin{array}{l}\text { Ornamental in } \\
\text { marine aquaria }\end{array}$ \\
\hline $\begin{array}{l}\text { Colpomenia peregrina } \\
\text { Sauvageau }\end{array}$ & Oyster Thief & 15 & $\begin{array}{l}\text { Sexual (dioecious), } \\
\text { vegetative } \\
\text { propagation abundant }\end{array}$ & \\
\hline Dasysiphonia sp. & A red alga & 50 & $\begin{array}{l}\text { Sexual (dioecious), } \\
\text { vegetative } \\
\text { propagation abundant }\end{array}$ & \\
\hline $\begin{array}{l}\text { Sargassum muticum } \\
\text { (Yendo) Fensholt }\end{array}$ & $\begin{array}{l}\text { Japanese } \\
\text { Wireweed }\end{array}$ & 200 & $\begin{array}{l}\text { Sexual (Self-fertile } \\
\text { monoecious) }\end{array}$ & \\
\hline $\begin{array}{l}\text { Undaria pinnatifida } \\
\text { (Harvey) Suringar }\end{array}$ & Wakame & 300 & $\begin{array}{l}\text { Sexual (many minute } \\
\text { gametophytes) }\end{array}$ & Food crop \\
\hline $\begin{array}{l}\text { Womersleysella setacea } \\
\text { (Hollenberg) R.E. Norris }\end{array}$ & A red alga & 10 & $\begin{array}{l}\text { Vegetative } \\
\text { propagation abundant }\end{array}$ & \\
\hline
\end{tabular}


Table 2. Sorting of simulation results based on AICw. E, exponential; TP, truncated power law; P, power law; $\mathrm{U}$, unclassified.

\begin{tabular}{|c|c|c|c|}
\hline Overall Result & $\begin{array}{l}\text { Breakdown of result } \\
\text { subset types }\end{array}$ & $\begin{array}{c}\text { Simulation based on } \\
\text { exponential dispersal (\%) }\end{array}$ & $\begin{array}{c}\text { Simulation based on } \\
\text { power law dispersal (\%) }\end{array}$ \\
\hline Exponential (All) & & 82 & 1 \\
\hline \multirow[t]{3}{*}{$\begin{array}{l}\text { Exponential } \\
\text { (subsets) }\end{array}$} & $\begin{array}{l}\text { E better than TP on } \\
\text { both tests }\end{array}$ & 2 & 0 \\
\hline & $\begin{array}{l}\text { Conflict between E } \\
\text { and TP, and E better } \\
\text { than P on both tests }\end{array}$ & 7 & 1 \\
\hline & $\begin{array}{l}\text { Default E, and E } \\
\text { better than P on both } \\
\text { tests }\end{array}$ & 73 & 0 \\
\hline $\begin{array}{l}\text { Truncated Pareto } \\
\text { (All) }\end{array}$ & $\begin{array}{l}\text { TP better than E on } \\
\text { both tests }\end{array}$ & 1 & 83 \\
\hline Unclassified, U & $\begin{array}{l}\text { All other } \\
\text { combinations }\end{array}$ & 17 & 16 \\
\hline
\end{tabular}
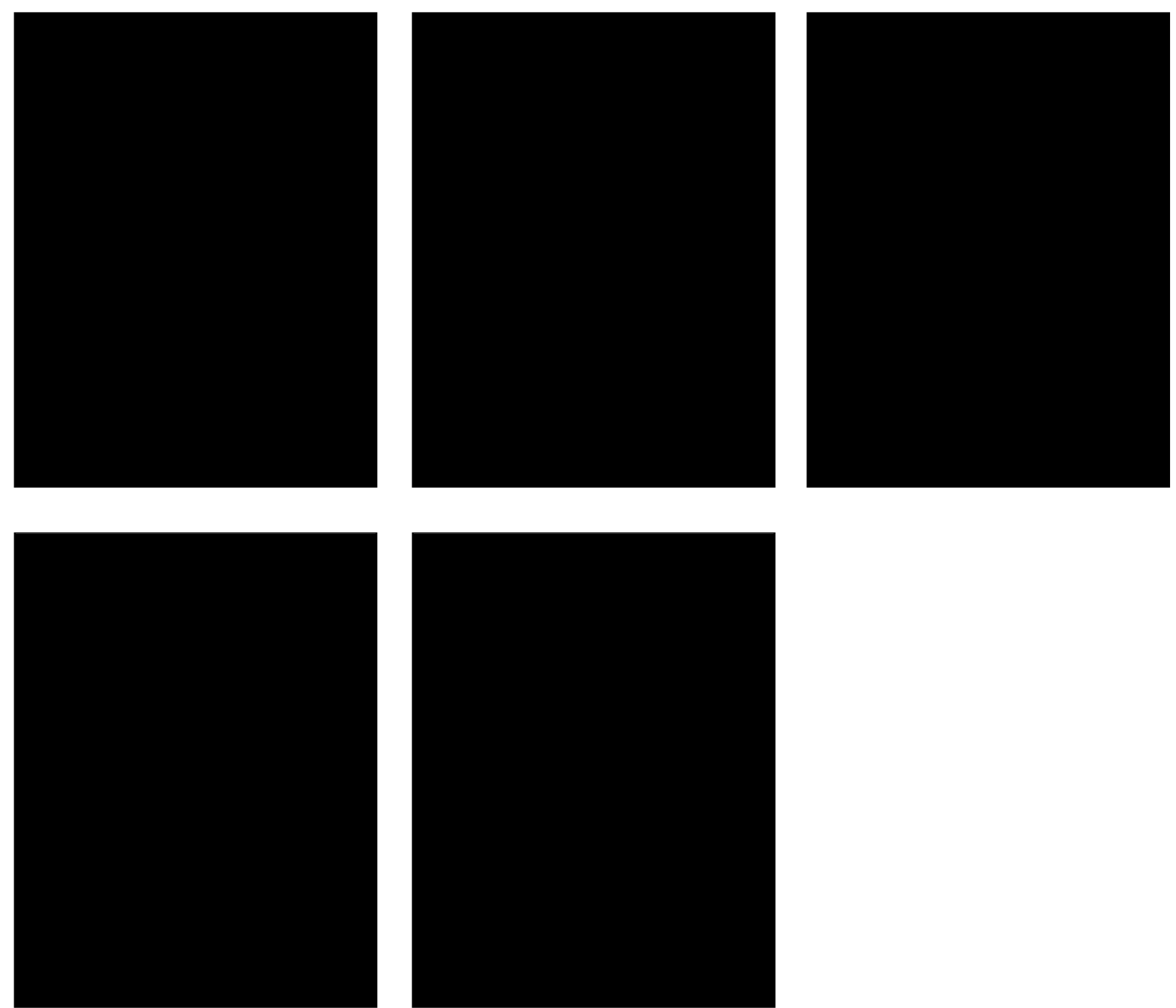

Fig. 1 Locations of freshwater invasive species records in Ireland; a) Azolla filiculoides, b) Elodea canadensis, c) Elodea nuttallii, d) Lagarosiphon major and e) Lemna minuta. 

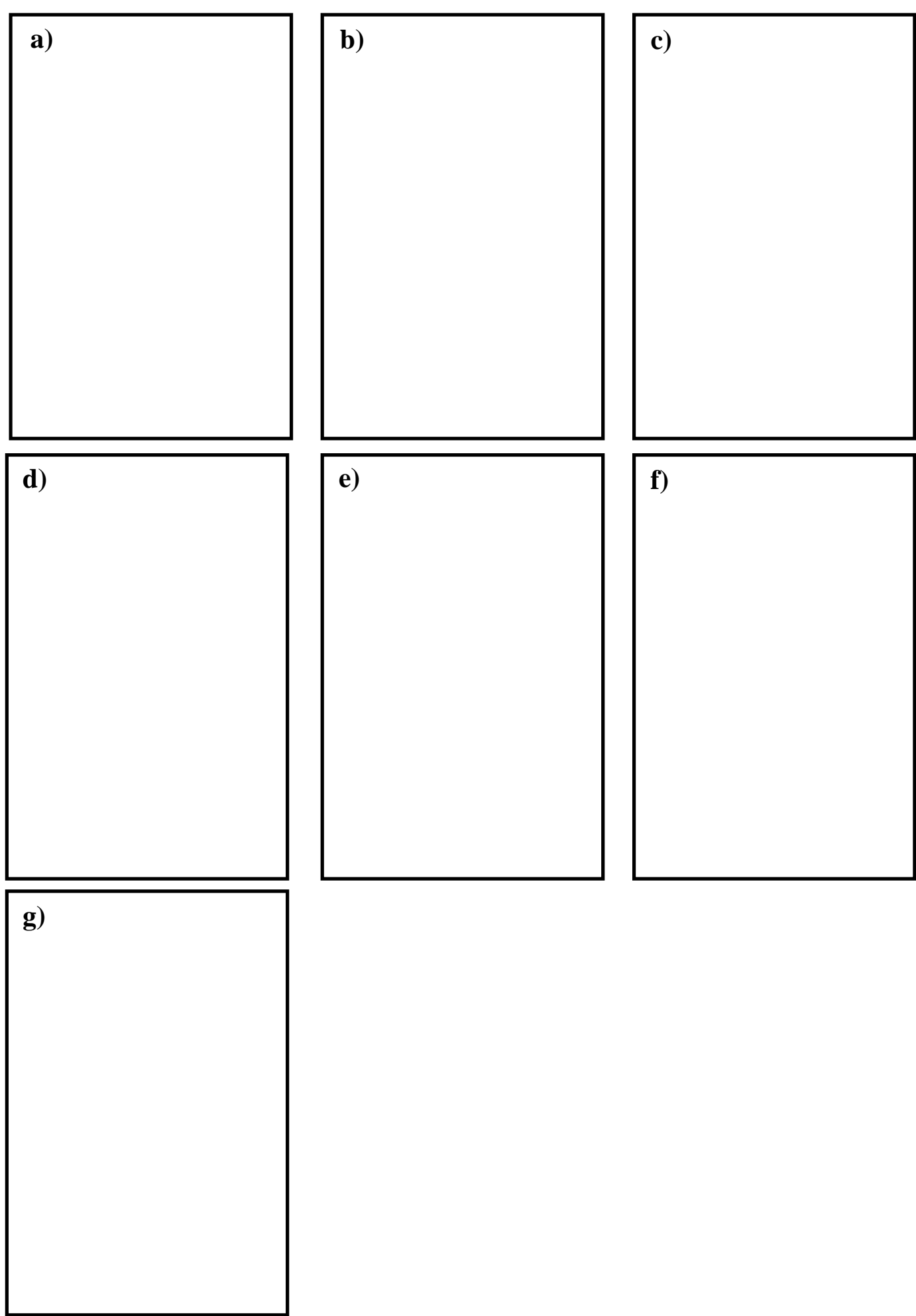

Fig. 2 Distribution of invasive algal species in the Atlantic Ocean. (a) Asparagopsis armata, (b) Antithamnionella ternifolia, (c) Codium fragile, (d) Colpomenia peregrina, (e) Dasysiphonia sp., (f) Sargassum muticum and (g) Undaria pinnatifida. 

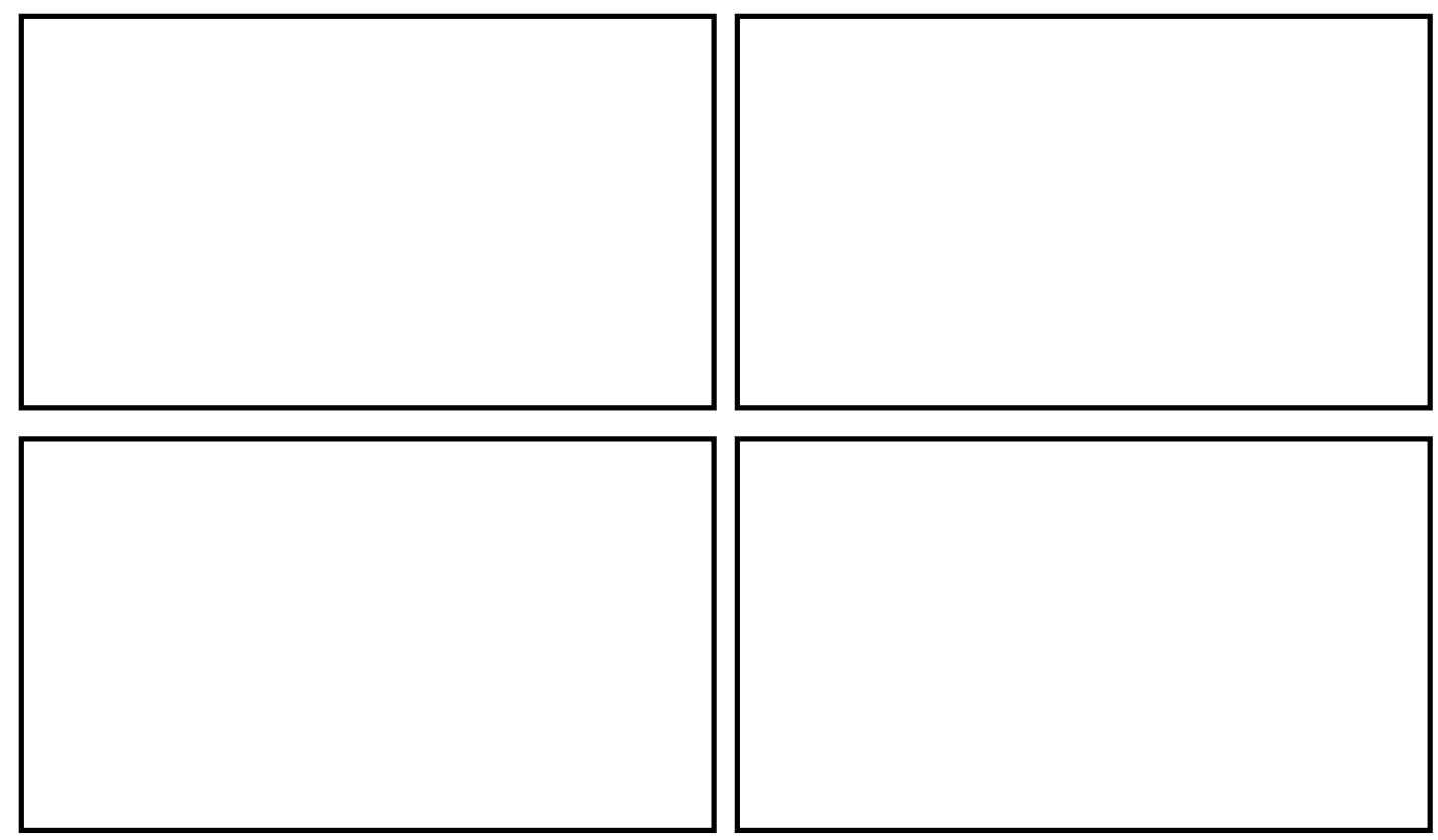

Fig. 3 Distribution of invasive Mediterranean species, a) Asparagopsis armata, b) Antithamnionella elegans, c) Caulerpa taxifolia and d) Womersleysella setacea.

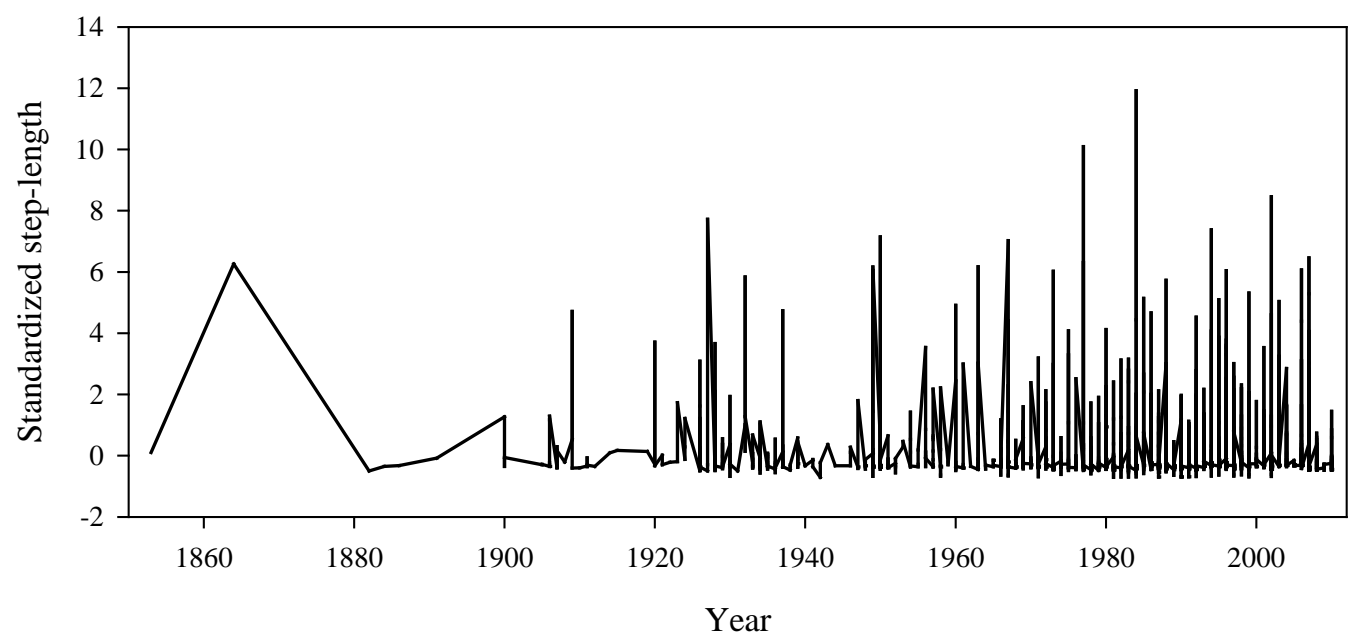

Fig. 4 Distribution of standardised step-length distances across time. Step-lengths of all 16 invasions (11 marine and 5 freshwater) plotted together. Step-lengths standardised to standard deviation in step length within species. Note that, whilst the frenquency of transport increases over time there long distance transport events are evident throughout the time line. 

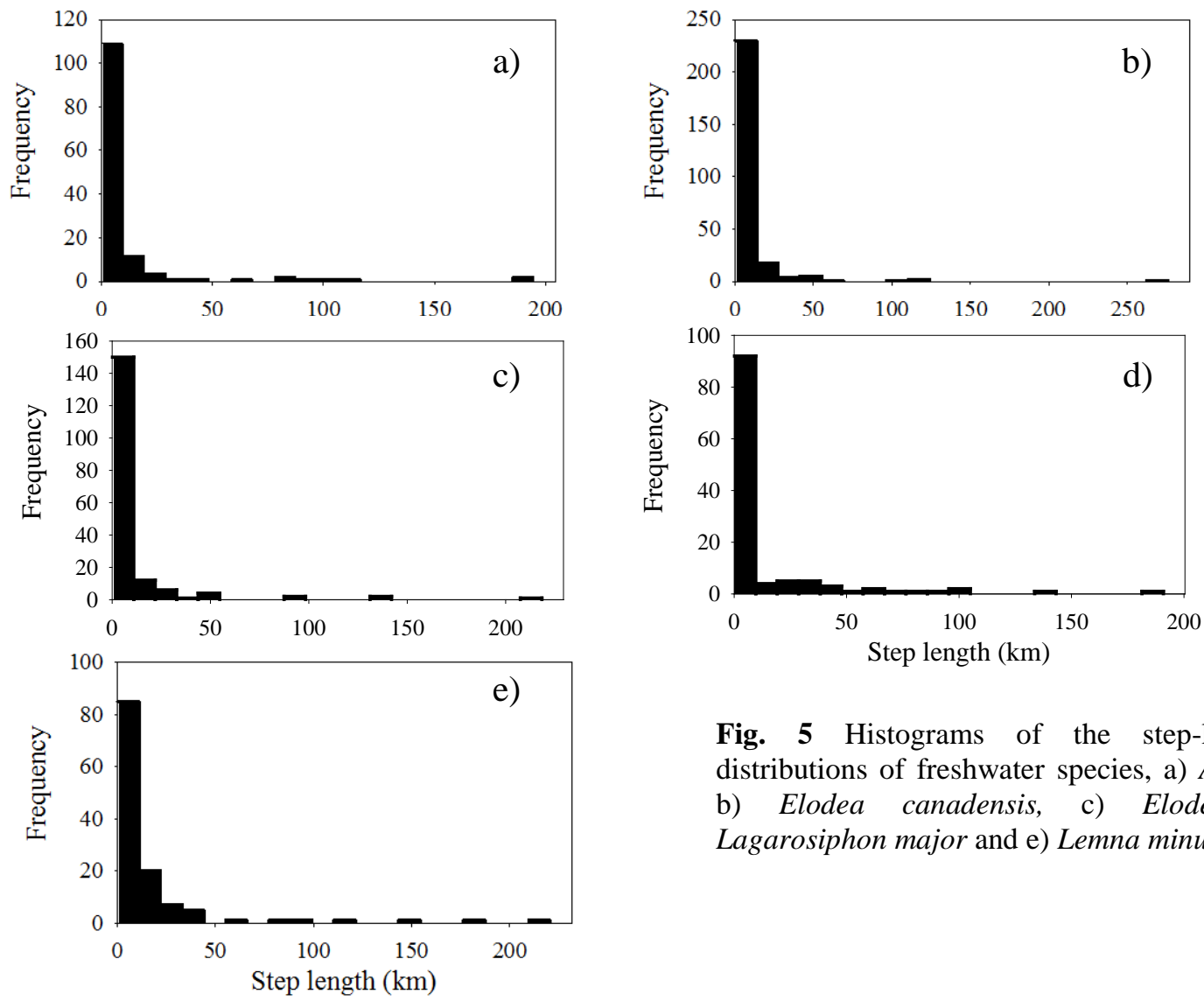

Fig. 5 Histograms of the step-length frequency distributions of freshwater species, a) Azolla filiculoides, b) Elodea canadensis, c) Elodea nuttallii, d) Lagarosiphon major and e) Lemna minuta. 

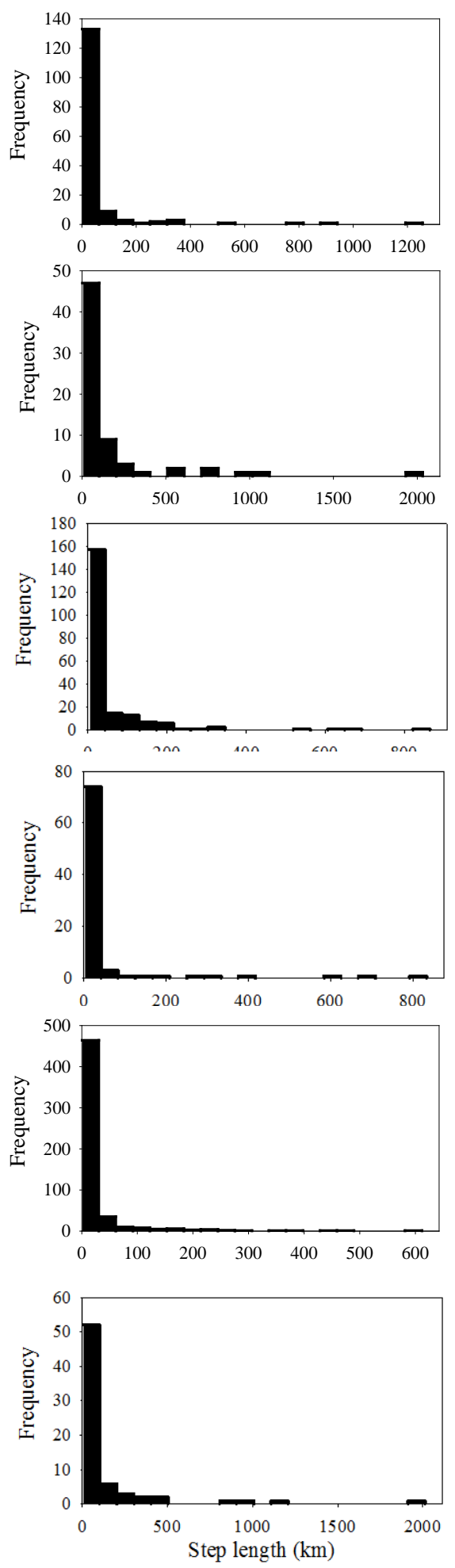
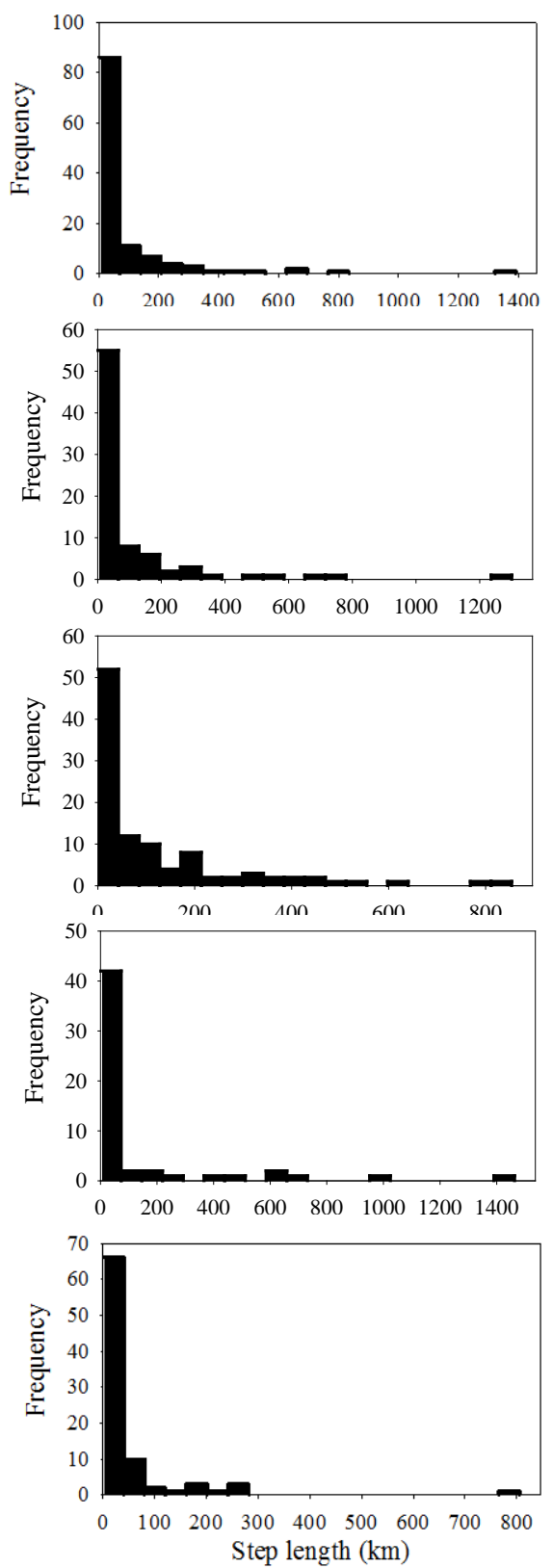

Fig. 6 Histograms of step length frequency in marine species. (a) Asparagopsis armata (Atl), (b) Asparagopsis armata (Med), (c) Antithamnionella elegans, (d) Antithamnionella ternifolia, (e)Codium fragile, (f) Colpomenia peregrine, (g) Caulerpa taxifolia, (h) Dasysiphonia sp., (i) Sargassum muticum, (j) Undaria pinnatifida and (k) Womersleysella setacea. 

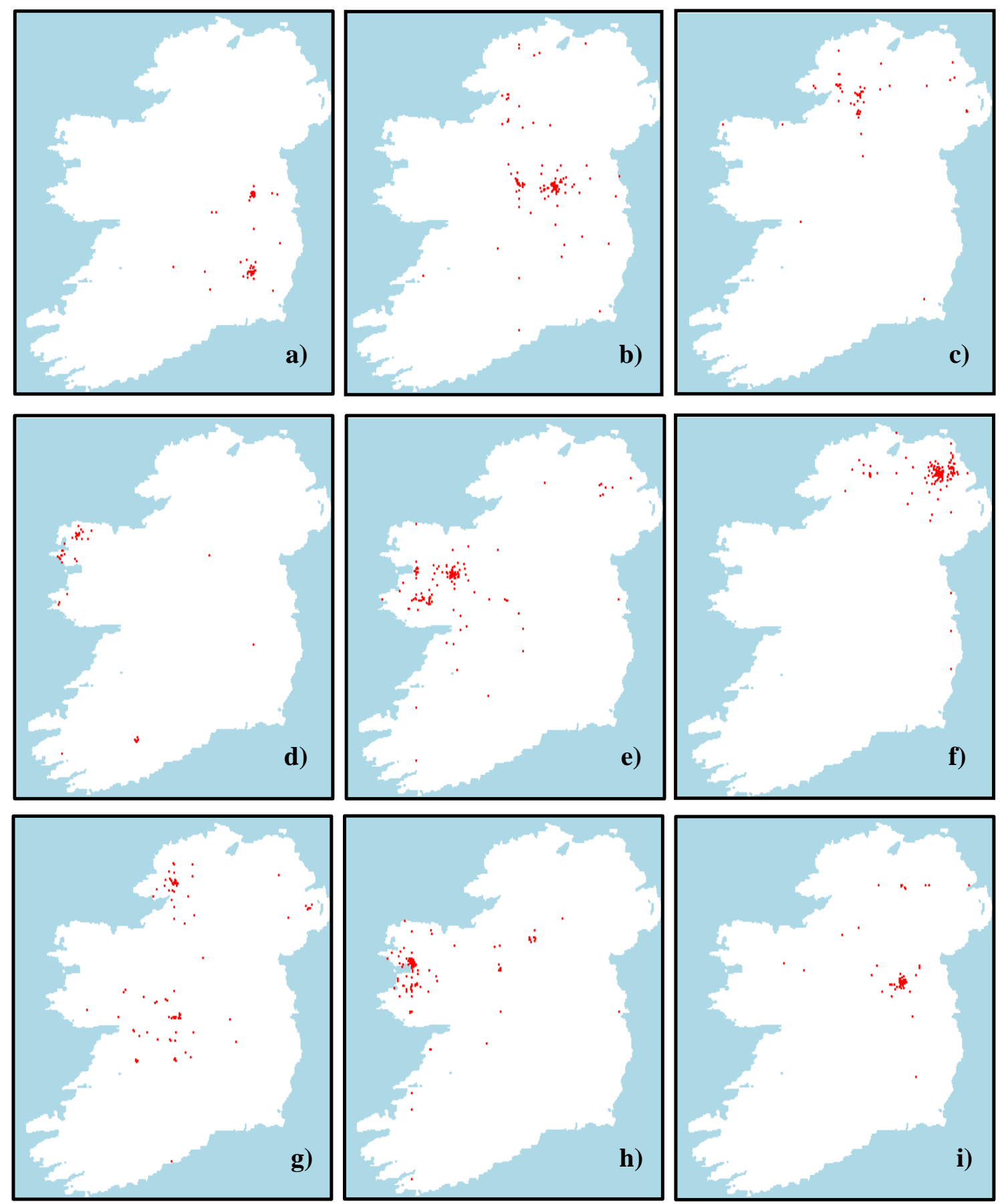

Fig. 7 Example plots of simulation model output based on power law (Lévy) dispersal. Images were selected at random from simulations, final number of points, a) 70, b) 143, c) 63, d) 55, e)175, f) 189, g) 120, h) 131 and i) 72 . 

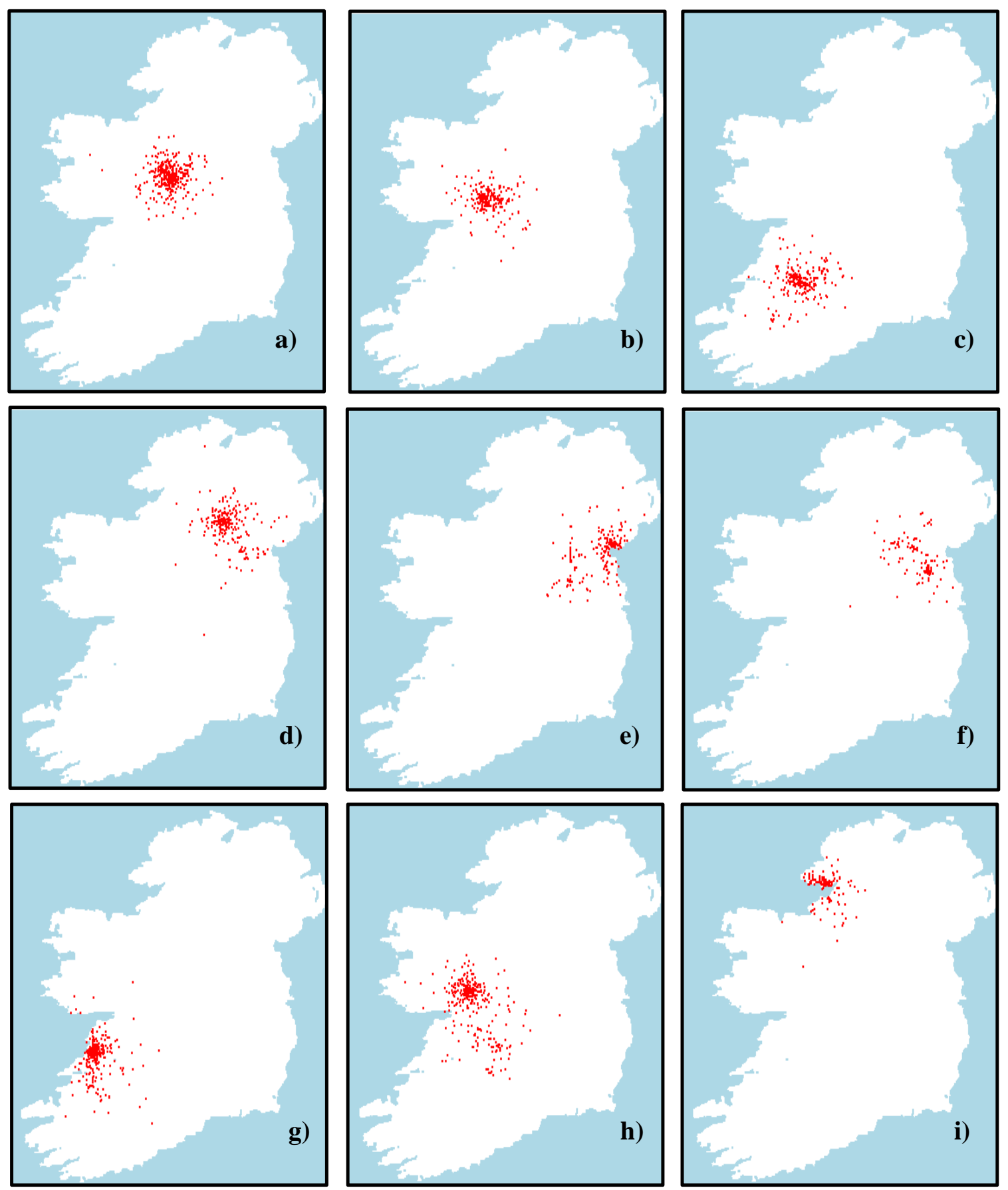

Fig. 8 Example plots of simulation model output based on exponential dispersal. Images were selected at random from simulations, final number of points (a) 419, (b) 239, (c) 229, (d) 251, (e) 227, (f) 115, (g) 316, (h) 351 and (i) 122. 